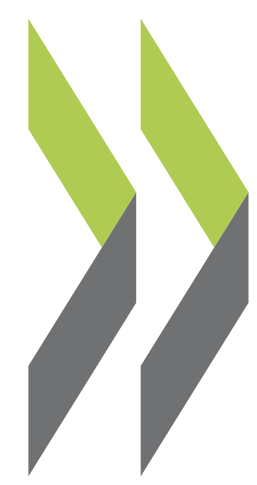

CELE Exchange, Centre for Effective Learning Environments $2011 / 01$

The Kunskapsskolan ("The Knowledge School"): A Personalised Approach to

\title{
Education
}

\section{Odd Eiken}

https://dx.doi.org/10.1787/5kgdzvmzjblv-en 


\section{The Kunskapsskolan ("the knowledge school"): a personalised approach to education}

By Odd Eiken*, Kunskapsskolan Education, Sweden

Kunskapsskolan is a chain of independent secondary schools which functions as a comprehensive platform for personalised education, known as the Kunskapsskolan programme (KED). What is special about this programme is that students set their own objectives, work independently and are assessed against their personal academic goals.

This article is not necessarily an endorsement by the OECD of the information contained therein.

Kunskapsskolan is a unique programme in that every step and element of learning is defined - from teachers' roles to IT and architecture - in order to facilitate personalised learning. This programme is operated in Kunskapsskolan's 33 secondary and upper secondary schools in Sweden and in 2 secondary schools in United Kingdom. The first US school will open this year in New York.

Every time a newspaper writes about education the article is illustrated with a picture of a school building. This building is not only a metaphor for education; it is also a denominator for how we traditionally organise education. The traditional school building is divided into classrooms, connected by corridors: these circulation zones are crowded once an hour, but of no use in between. In many countries even the size of classrooms is defined by state regulations, which mould its physical organisation. Put 20-40 students in every classroom and you need at least one adult in every room; this determines the allocation of the work force. This combination of classroom, teacher and students shapes the pedagogy within its walls: staff generally try to calibrate their teaching to suit the average students in the classroom, even at the risk of losing the low performers along the way.

This way, the "equation of education" in a traditional school starts with a building and ends with the individual student: his/her needs and learning capacity are residual. The recipe underpinning KED is to turn that equation around. Start with the individual student and a vision based on the premise that what we need to learn, how we do it best and what kind of support and environment that calls for varies between - and within - individuals, depending on the situation. Create a process of understanding and defining needs and goals; set tasks and slice them into manageable and assessable chunks. Then design every element and resource to provide optimal support for this concept. This is the basic idea.

* Mr. Eiken was previously State Secretary of Education in the Swedish government and held several positions in government, international organisations and the business sector. 
Architectural design is an important and often recognised part of the concept but, even so, it is the last part of our equation. Our buildings' sole purpose is to support learning among individual students.

KED schools personalise students' education through a combination of goal setting, weekly coaching, personalised scheduling and timing and a unique curriculum maintained on the web-based Learning Portal. Students study according to different lesson formats, ranging from lectures and workshops to seminars and laboratories, depending on tasks and needs. Parents, students and teachers/coaches meet at the start of every term to decide on each student's individual educational plan and long-term goal. Students then have weekly meetings with their coach to discuss their goals, schedule, and whether they have met the goals set in previous meetings. Over time, students develop personal responsibility for, and ownership of, what they learn.

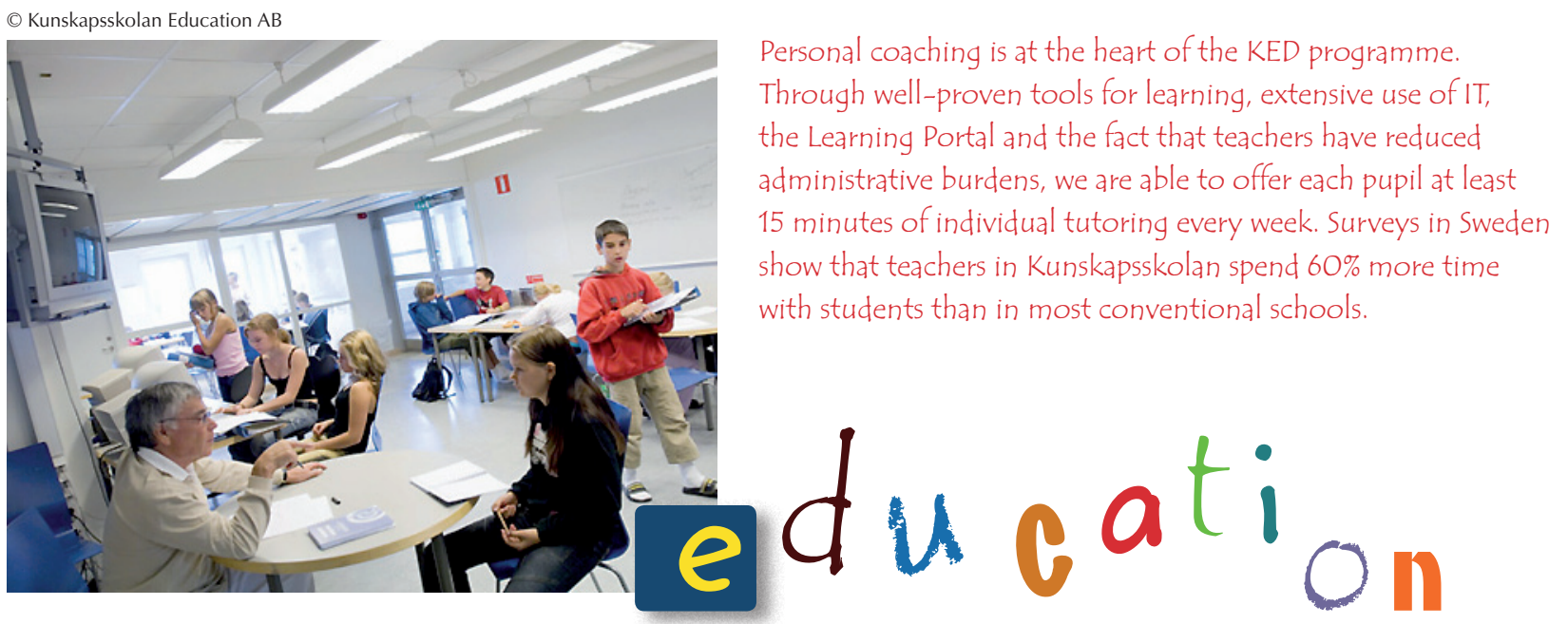

The core tenet of the programme is the process whereby each individual student sets and works towards personalised academic goals. These are short term (weekly), medium term (the semester) and long term; they are continuously assessed and revised.

Each student is assigned a teacher as his or her personal coach. This teacher supports the student when setting goals, designing the learning strategy to reach the goals and assessing performance.

The schools' approach and key resources are designed to support this process of personalised learning:

- Teachers have multiple roles. Besides being a subject teacher, each one also acts as a general coach and gives direct support to students, as well as being a personal coach for some 20 students.

- The timetable is flexible. This allows students to attend a number of group lessons, presentations, individual study sessions and teacher-led workshops. Timetables for individual students are finalised during the weekly coaching session in function of how the student and his/her coach assess progress, individual goals and forward-looking strategy.

- Every student has his/her goals, as does every teacher and every school, and progress is continuously monitored and assessed. Performance data in relation to students' academic performance as well as schools' operational performance is continuously collected and assessed. KED's philosophy is that learning should not be a random outcome of doing your best; it is a process that can be mastered and controlled, if structured with goals in digestible pieces. 
- The school offers a variety of learning formats, ranging from group lectures and teacher-led communication sessions to workshops where teachers are available to guide individual studies. Rather than belonging to a specific class, students belong to a base group even though they have personalised timetables and spend time in various group formations. Some of these activities are compulsory and some are voluntary; together they provide the student with the means to access the blend of instruction, collaboration and individual work which is optimal for their particular learning task.

- The curriculum is designed in steps. This enables students to progress on an individual basis without being tied to a class or grade. In addition to these steps, students are offered thematic courses that cut across a number of subjects. These can also provide analysis and insights into the overall study context and across disciplines.

- All resources, meaning the curriculum, syllabus, steps, texts and assignments, are to be found on the web-based Learning Portal. This way students can access assignments and resources whenever and wherever they wish via the Internet. The Learning Portal is not only a resource bank for students; it also gives parents insights into their children's learning. The teachers' pages of the Portal serve as a knowledge management tool for all teachers and principals. Teachers' resources - such as presentations, planning tools and lessons - are also found on the teachers' pages and all teachers in Kunskapsskolan participate in the continuous development of the portal. This is an important organisational aspect, because one of the aims of the programme is to free up teachers' time from administrative and preparatory work that could be used for high-quality coaching.

KED's architectural programme, which has been developed over the years by all our school principals, teachers and our architect Kenneth Gärdestad, is the last important element in this equation. The starting point is not to divide space into static classrooms with connecting corridors, but to regard the entire space as a potential learning area. Rooms are conceived in different shapes and sizes; they range from a large arena to rooms for small groups and have sliding glass walls. Most areas have multiple functions. The laboratory also serves as a base group room, the cafeteria doubles up as a space suitable for collaboration or as a study area before and after lunch time, and all spaces in between rooms are learning spaces equipped with work stations where students can interact, read or log in to the Portal and carry on working.

() Kunskapsskolan Education $\mathrm{A}$

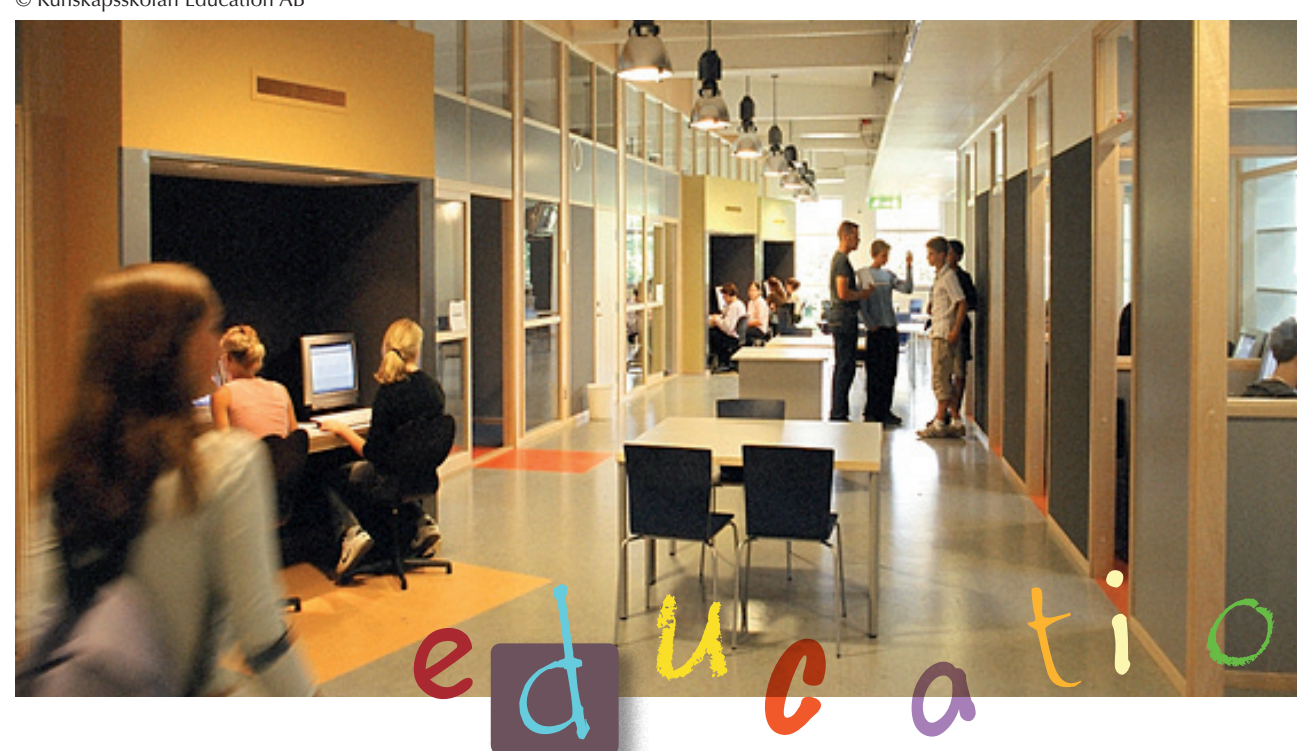

There are no corridors in Kunskapsskolan's architectural programme. All spaces are potential learning spaces and can be used for collaborative purposes or individual studies. Empty spaces are converted to work stations, where students can log in to the Portal and continue their learning outside of class hours. 


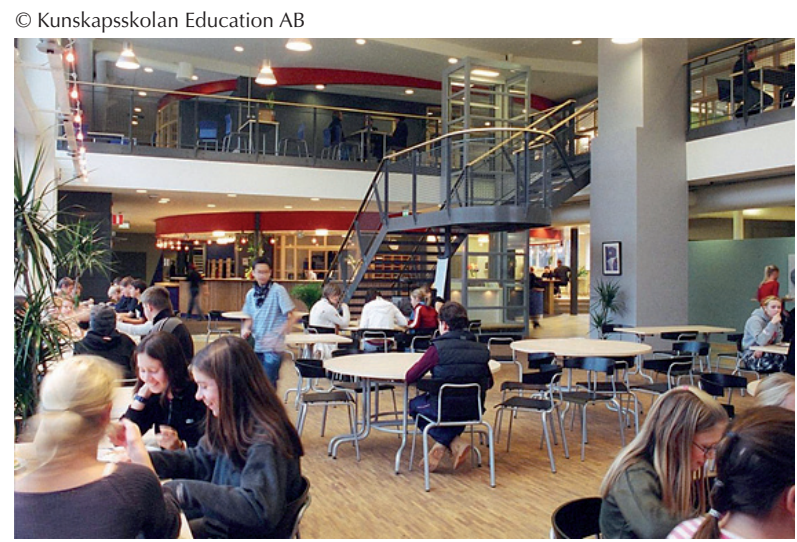

Open space, visibility and multiple usage of spaces are all pillars of KED's architectural programme. Every space - including the cafeteria - is a learning space.

Kunskapsskolan's schools are typically located in facilities which were originally built for other purposes, i.e. former office buildings, factories or shops. But the architecture, characterised by light, visibility and flexibility, does not only allow for a more effective use of space (the average amount of space per student is between 7-9 $\mathrm{m}^{2}$ ); it also gives rise to an open and collaborative atmosphere where the idea that every space is a learning space is omnipresent. This concept also gives schools the flexibility to adapt to changing conditions. An office converted into a school could be converted back entirely or partly if demographics or demand were to change.

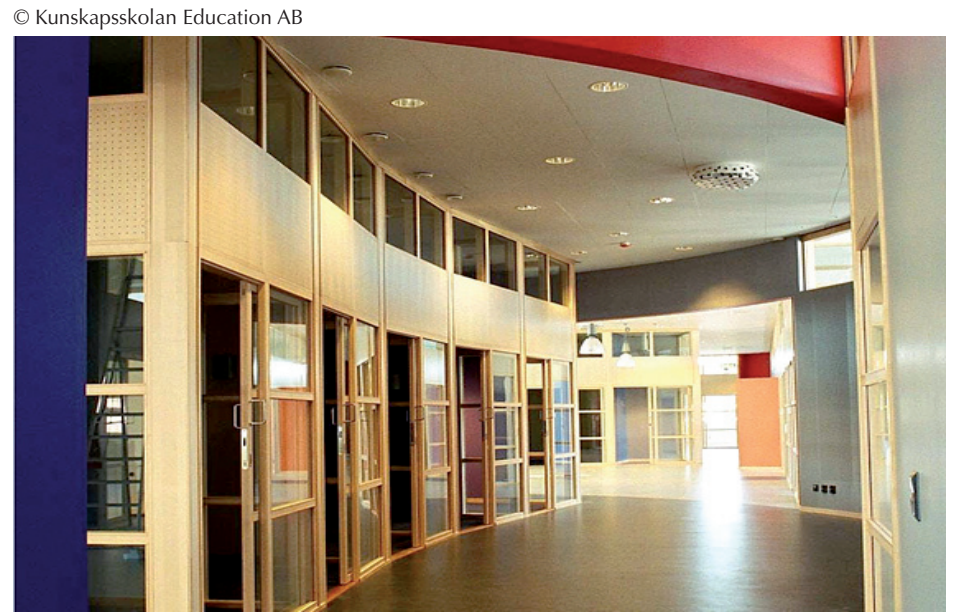

Instead of standardised classrooms, rooms have different shapes and sizes. Common features of all rooms are light, openness and the extensive use of glass. This facilitates seeing and being seen.

Visitors to Kunskapsskolan often remark that our schools look more like the site of a modern, creative knowledge industry rather than a traditional school. That may well be so, and after all, isn't that the kind of working life the next generation needs to prepare for?

For more information, contact:

Odd Eiken

Executive Vice President

Kunskapsskolan Education

Box 92146

SE 12008 Stockholm

Sweden

www.kunskapsskolan.com

E-mail: Odd.Eiken@kunskapsskolan.se 


\section{ORGANISATION FOR ECONOMIC CO-OPERATION AND DEVELOPMENT}

The OECD is a unique forum where governments work together to address the economic, social and environmental challenges of globalisation. The OECD is also at the forefront of efforts to understand and to help governments respond to new developments and concerns, such as corporate governance, the information economy and the challenges of an ageing population. The Organisation provides a setting where governments can compare policy experiences, seek answers to common problems, identify good practice and work to co-ordinate domestic and international policies.

The OECD member countries are: Australia, Austria, Belgium, Canada, Chile, the Czech Republic, Denmark, Estonia, Finland, France, Germany, Greece, Hungary, Iceland, Ireland, Israel, Italy, Japan, Korea, Luxembourg, Mexico, the Netherlands, New Zealand, Norway, Poland, Portugal, the Slovak Republic, Slovenia, Spain, Sweden, Switzerland, Turkey, the United Kingdom and the United States. The European Commission takes part in the work of the OECD.

OECD Publishing disseminates widely the results of the Organisation's statistics gathering and research on economic, social and environmental issues, as well as the conventions, guidelines and standards agreed by its members.

This work is published on the responsibility of the Secretary-General of the OECD. The opinions expressed and arguments employed herein do not necessarily reflect the official views of the Organisation or of the governments of its member countries.

You can copy, download or print OECD content for your own use, and you can include excerpts from OECD publications, databases and multimedia products in your own documents, presentations, blogs, websites and teaching materials, provided that suitable acknowledgment of OECD as source and copyright owner is given. All requests for public or commercial use and translation rights should be submitted to rights@oecd.org. Requests for permission to photocopy portions of this material for public or commercial use shall be addressed directly to the Copyright Clearance Center (CCC) at info@copyright.com or the Centre français d'exploitation du droit de copie (CFC) at contact@cfcopies.com. 